\title{
Studies of Transcriptional Regulation of the Bacillus subtilis Developmental Gene spoVE
}

\author{
By U. D. BUGAICHUK† \\ Microbiology Unit, Department of Biochemistry, University of Oxford, South Parks Road, \\ Oxford OXI $3 Q U, U K$
}

(Received 7 January 1987; revised 21 May 1987)

\begin{abstract}
The structural gene of the spoVE locus of Bacillus subtilis was replaced with the promoterless lac $Z$ gene of Escherichia coli. The spoVE: $:$ lac $Z$ gene fusion was transferred to the $B$. subtilis chromosome and $\beta$-galactosidase activity was measured under sporulation conditions. Expression of the hybrid gene could be detected as early as $40 \mathrm{~min}$ after the induction of sporulation. Transcription of the spoVE : :lacZ gene was dependent on the products of two stage 0 loci, spoOH and spoOK. Mutations in the spoIIA and spoIIG loci did not impede expression of spoVE and, therefore, neither of the sigma factors coded for by these loci seems to be necessary for its transcription. Consequently, the spoVE locus does not seem to be part of the dependent sequence of operons involved in the developmental change, although its protein product is clearly needed for the completion of spore formation.
\end{abstract}

\section{INTRODUCTION}

The morphological changes of the later stages of sporulation in Bacillus subtilis may be separated in time from the underlying biochemical processes (Dion \& Mandelstam, 1980; Jenkinson et al., 1980, 1981). Studies of the formation of the spore coat and the concomitant development of resistance properties have demonstrated that these are a result of self-assembly of proteins that are synthesized earlier. It is therefore not surprising to find that some stage $\mathrm{V}$ loci are expressed early in sporulation, i.e. well before the morphological changes characteristic of this stage are observed. Studies of transcriptional regulation of spoVG (Zuber \& Losick, 1983) and spoVA (Savva \& Mandelstam, 1985; Errington \& Mandelstam, 1986) have revealed that these loci are transcribed at about $t_{0}$ and $t_{2.5}$, respectively. The results of these and many other experiments support the conclusion that almost all spo loci are expressed within $4 \mathrm{~h}$ of the onset of sporulation (Dion \& Mandelstam, 1980; Jenkinson et al., 1980, 1981).

Cloning and sequencing of spoVE (Piggot et al., 1986; Bugaichuk \& Piggot, 1986) provided data on the size and the structure of this locus. Its physiological function, however, cannot be understood without knowing when this gene is activated and to what extent its expression depends on other spo loci. To study this aspect of the role of spoVE in sporulation a promoterless copy of the Escherichia coli $\beta$-galactosidase gene, lac $Z$, was fused to the regulatory elements of spoVE. By measuring $\beta$-galactosidase activity in sporulating $B$. subtilis cells, $I$ have now shown that the expression of the spoVE gene commences about $40 \mathrm{~min}$ after induction of sporulation and is prevented by mutations in two stage 0 loci.

† Present address: CRC Chromosome Molecular Biology Group, Department of Biochemistry, University of Oxford, South Parks Road, Oxford OXI 3QU, UK.

Abbreviation: MUG, 4-methylumbelliferyl $\beta$-D-galactoside. 
Table 1. Bacterial strains and plasmids

\begin{tabular}{|c|c|c|}
\hline Bacteria & Genotype & Source/reference \\
\hline \multicolumn{3}{|l|}{ B. subtilis } \\
\hline 17 & spoOH17 trpC2 & \\
\hline 43.2 & spo0A43 leu-8 rif-2 tal-1 & \\
\hline 55.3 & spoIIG55 trpC2 & \\
\hline 69 & spoIIAA69 trpC2 & \\
\hline MB75 & $\left(\mathrm{Spo}^{+}\right)$metC3 lys-I tal-1 & \\
\hline 87.2 & spo0J87 leu-8 & \\
\hline 93.2 & spo0J93 trpC2 & Laboratory stock \\
\hline 141 & spooK141 trpC2 & \\
\hline 168 & $\left(\mathrm{Spo}^{+}\right) \operatorname{trp} C 2$ & \\
\hline 221.1 & spoOF $221 \operatorname{trp} C 2$ & \\
\hline 484.2 & spoOEII trpC2 & \\
\hline 485.1 & spo0G14 lys-1 & \\
\hline 486 & spo0D8 trpC2 & \\
\hline 488.4 & spo0B136 trpC2 & \\
\hline MY2000.63 & spoIIAC63 lys-1 pyrD1 rif & M. D. Yudkin, University of Oxford \\
\hline KSV & spoVG : :Tn917 trpC2 (MLSR) & $\begin{array}{l}\text { Transformation of strain } 168 \text { with DNA from strain } \\
\text { KS265 and selection for MLS * }\end{array}$ \\
\hline BS50 & $\left(\mathrm{Spo}^{+}\right) \operatorname{trp} C 2$ spoVE $:: \operatorname{lac} Z$ & This paper \\
\hline \multicolumn{3}{|l|}{ E. coli } \\
\hline JM103 & $\begin{array}{l}\text { supE } s b c B 15 \text { str } A \text { thi } \\
\text { end } A \Delta(\text { lac-proAB })\left[\mathrm{F}^{\prime}\right. \\
\text { traD36 proAB lacI } \\
Z \Delta M 15]\end{array}$ & Messing et al. (1981) \\
\hline JM107 & $\begin{array}{l}\text { endAl gyrA96 hsdRI7 } \\
\text { supE44 relAl thi } \\
\triangle(\text { lac-proAB })\left[\mathrm{F}^{\prime} \text { traD36 }\right. \\
\text { pro } A B \text { lacI } \mathrm{Z} \triangle M 15]\end{array}$ & Yanisch-Perron et al. (1985) \\
\hline Plasmids & Relevant characteristics & Reference \\
\hline pUC18 & bla lacZ' & Norrander et al. (1983) \\
\hline $\begin{array}{l}\text { pSGMU32 } \\
\text { pUB4 }\end{array}$ & $\begin{array}{l}\text { bla lacZ cat } \\
\text { bla; } 1.35 \mathrm{kbp} \text { XhoI fragment }\end{array}$ & Errington (1986) \\
\hline & $\begin{array}{l}\text { of spoVE cloned in Sall } \\
\text { site of pUC9 }\end{array}$ & \\
\hline pUB5 & $\begin{array}{l}\text { bla spoVE: : lacZ'; deletion } \\
\text { of } 500 \mathrm{bp} \text { AvaI fragment } \\
\text { of pUB4 }\end{array}$ & Bugaichuk \& Piggot (1986) \\
\hline pVL3 & $\begin{array}{l}\text { bla } ; 800 \text { bp fragment of } \\
\text { spoVE locus inserted in pUC18 }\end{array}$ & \\
\hline $\begin{array}{l}\text { pVL50 } \\
\text { pLM14 }\end{array}$ & $\begin{array}{l}\text { bla cat spoVE: :lacZ } \\
\text { bla cat spoVE: :lacZ }\end{array}$ & This paper \\
\hline
\end{tabular}

* DNA from strain KS265 was a gift from K. Sandman (Harvard Univesity, USA). MLSR, resistance to macrolide, lincosamide and streptogramin B antibiotics.

\section{METHODS}

Bacterial strains. These are listed in Table 1.

Growth and sporulation. B. subtilis cells were grown in hydrolysed casein medium $(\mathrm{CH})$ and induced to sporulate as described by Sterlini \& Mandelstam (1969).

Transformation. The B. subtilis strains were transformed by the method of Anagnostopoulos \& Spizizen (1961). Transformants were selected on Oxoid nutrient agar (NA) plates supplemented with chloramphenicol $(\mathrm{Cm})$ at a concentration of $5 \mu \mathrm{g} \mathrm{ml}^{-1}$. Strain KSV was selected on NA containing erythromycin, $1 \mu \mathrm{g} \mathrm{ml}^{-1}$, and lincomycin, $25 \mu \mathrm{g} \mathrm{ml}^{-1}$. For rapid detection of $\beta$-galactosidase activity on plates Schaeffer's agar (Schaeffer et al., 1965) containing $30 \mu \mathrm{g} 4$-methylumbelliferyl $\beta$-D-galactoside (MUG) $\mathrm{ml}^{-1}$ (Youngman et al., 1985a, b) was used. E. coli strains were transformed by the method of Hanahan (1983). Strains were maintained on LB agar; chloramphenicol $(\mathrm{Cm})$ or ampicillin (Ap) were added, when necessary, at concentrations of $10 \mu \mathrm{g} \mathrm{ml}^{-1}$ and $50 \mu \mathrm{g} \mathrm{ml}^{-1}$, respectively. To detect expression of the lac $Z$ gene, 5-bromo-4-chloro-3-indolyl $\beta$-D-galactopyranoside (Xgal) was added to media at a concentration $40 \mu \mathrm{g} \mathrm{ml}^{-1}$. 
Plasmids. Plasmids and their sources are described in Table 1. Plasmids were isolated from $E$. coli as described by Birnboim \& Doly (1979). Small-scale rapid screening of recombinant plasmids was performed as described by Maniatis et al. (1982).

$\beta$-Galactosidase assays. $B$. subtilis cells harbouring the spoVE : : lacZ fusion were grown and induced to sporulate as described by Sterlini \& Mandelstam (1969). Samples were taken at intervals, centrifuged and quickly frozen. After thawing at room temperature cells were washed and resuspended in $Z$ buffer $(1 \mathrm{ml})$, toluenized and assayed for $\beta$-galactosidase activity as described by Miller (1972). One unit of specific $\beta$-galactosidase activity is defined as the amount of enzyme that releases $1 \mathrm{nmol} o$-nitrophenol $\mathrm{min}^{-1}$ at $28^{\circ} \mathrm{C}$.

Construction of plasmid pVL3. Plasmid pUB5, which contains a translational spoVE: :lac $Z^{\prime}$ gene fusion (Bugaichuk \& Piggot, 1986), was digested with PstI and treated with T4 DNA polymerase to blunt $3^{\prime}$ protruding cohesive ends. Plasmid DNA was purified and a second digestion with AvaI was carried out. The products of the reaction were separated by electrophoresis on $0.5 \%$ low-melting-point agarose and the $0.8 \mathrm{kbp}$ fragment of the spoVE gene was isolated and purified. This fragment was inserted into plasmid pUC18 prepared in the same way as described above, except that $S s t$ I was used to linearize the plasmid. The new plasmid was propagated in $E$. coli strain JMI03 and designated pVL3.

Treatment of DNA with Bal31. Fragments of the spoVE locus to be used for constructing transcriptional spoVE : : lacZ fusions (Fig. 1) were prepared as follows. Plasmid pUB4 was cleaved at its unique NcoI site and treated with $B a l 31$ (BRL) to reduce the $\mathrm{N}$-terminal coding portion of the spoVE gene to a desirable size. The conditions of the reaction were adjusted to set the rate of DNA degradation at about $100 \mathrm{bp} \mathrm{m^{-1 }}$ at each end. The reaction was stopped by plunging the tube into liquid nitrogen. Treated DNA was purified with phenol and precipitated in ethanol. To increase the number of blunt ends the DNA was treated with the Klenow fragment of $E$. coli DNA polymerase I. The residual DNA encoding the C-terminal region of the $s p o V E$ gene was removed by BamHI digestion.

\section{RESULTS}

\section{Construction of transcriptional spoVE : : lac Z gene fusions}

To study the regulation of the spoVE gene the method of 'gene fusion' was used to put the $E$. coli $\beta$-galactosidase gene (lacZ) under the control of the spoVE regulatory signals.

The transcriptional spoVE : :lacZ fusions were constructed in vitro as outlined in Fig. 1 . The plasmid pVL3 was linearized with SmaI and PstI endonucleases and purified by electrophoresis

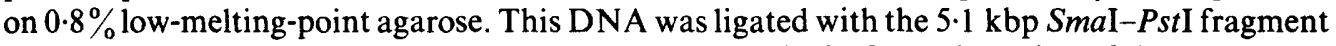
of pSGMU32, in which the lac $Z$ gene had been altered by in-frame insertion of the translation initiation start derived from the spoIIAA gene (Errington, 1986). Ligated DNA was transformed into $E$. coli strain $\mathrm{JM} 07\left[\mathrm{~F}^{-}\right]$. The pool of $\mathrm{Ap}^{\mathrm{R}}$ transformants was screened for the $\mathrm{Lac}^{+}$ phenotype and several positive clones were selected for further analysis. All of them were found to contain the same type of plasmid, which was designated pVL50. The orientation of the insert in relation to the regulatory region of the spoVE gene was confirmed by restriction analysis. Construction of the plasmid pLM14 was similar to that of pVL50 except that a smaller fragment of spoVE was used (see Fig. 1).

\section{Transfer of the spoVE: :lacZ fusions to the B. subtilis chromosome}

Plasmids pVL50 and pLM14 cannot replicate autonomously in $B$. subtilis since they lack a functional origin of replication. However, the presence of $s p o V E$ fragments within them makes it possible for these plasmids to become integrated into the chromosome by a Campbell-type mechanism. Bacteria with an integrated plasmid can be isolated by selecting for resistance to chloramphenicol. Transformation of $B$. subtilis strains 168 and MB75 (both $\mathrm{Spo}^{+}$) by these plasmids gave rise to chloramphenicol-resistant transformants with a $\mathrm{Spo}^{+}$phenotype. The appearance of transformants with such a phenotype indicates that the chromosomal fragments of plasmids pVL50 and pLM14 contain a transcription-initiation site capable of directing the expression of the spoVE transcriptional unit (Piggot et al., 1984). Fifty $\mathrm{Cm}^{R}$ clones from each transformation were subcultured on $\mathrm{NA}+\mathrm{Cm}$, and then transferred to Schaeffer's agar supplemented with MUG. After incubation for $24 \mathrm{~h}$ at $37^{\circ} \mathrm{C}$ the vast majority of colonies derived from the transformations with pVL50 and LM14 were brightly fluorescent when viewed under UV light. 
(a)

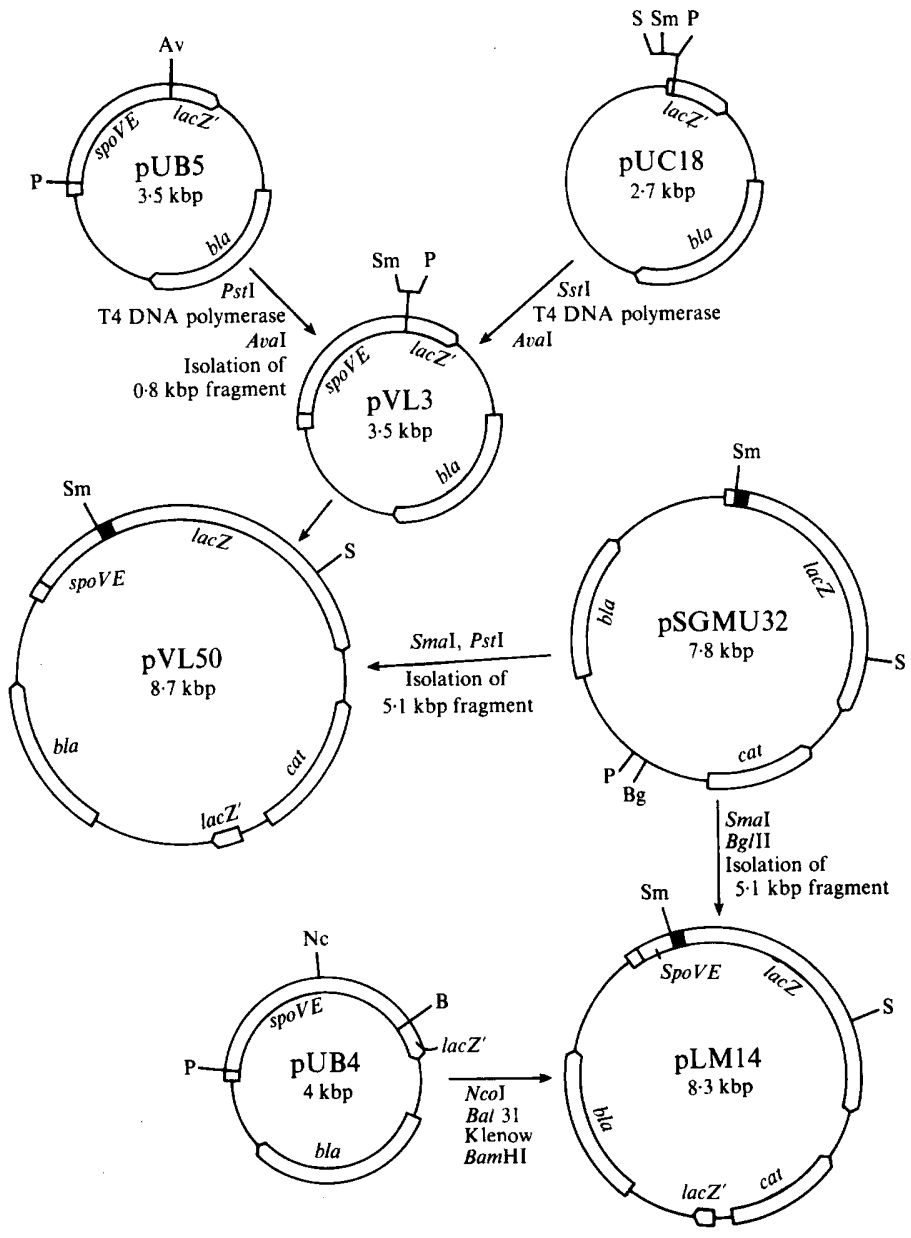

(b)
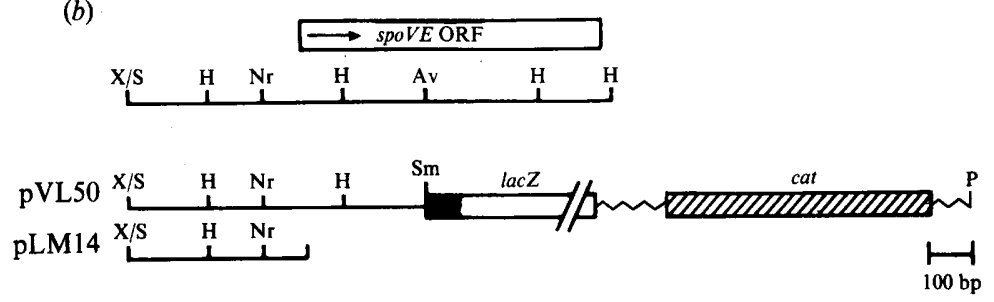

Fig. 1. Schematic representation of transcriptional spoVE : : lac $Z$ fusions. Part (a) depicts the construction of plasmids pVL50 and pLM14 (the scale is approximate). Regions coding for $\beta$-lactamase (bla), chloramphenicol resistance (cat) and $\beta$-galactosidase (lacZ) are shown as open boxes with the pointed end indicating the direction of transcription and translation. lac $Z^{\prime}$ corresponds to a region of DNA encoding only the amino-terminal portion of $\beta$-galactosidase. Only relevant restriction sites are shown. Treatment with the Klenow fragment of DNA polymerase I is indicated as 'Klenow'. 'Bal31' refers to the removal of double-stranded DNA with Bal31 exonuclease. Part $(b)$ shows the junction area of transcriptional spoVE : lac $Z$ fusions. The topmost line shows a restriction map of the spoVE locus. The open box indicates the location and length of the structural part of the spoVE gene; the arrow shows the direction of transcription. Fragments of the spoVE gene used for construction of transcriptional fusions are depicted as solid lines. Restriction sites: Av, AvaI; B, BamHI; Bg, BgIII; H, HindIII; Nc, NcoI; Nr, NruI; P, PstI; S, SstI; Sm, SmaI; X, XhoI. The lac-cat fragment was derived from plasmid pSGMU 32 by digestion with enzymes $S m a I$ and $P$ stI or SmaI and $B g l I I$. The $l a c Z$ gene and the cat gene are shown as an open box and a hatched box, respectively. The spoIIA fragment containing the ribosome-binding site of ORF1 is shown as a filled box in front of lacZ. The zig-zag line denotes noncoding DNA of plasmid origin. 

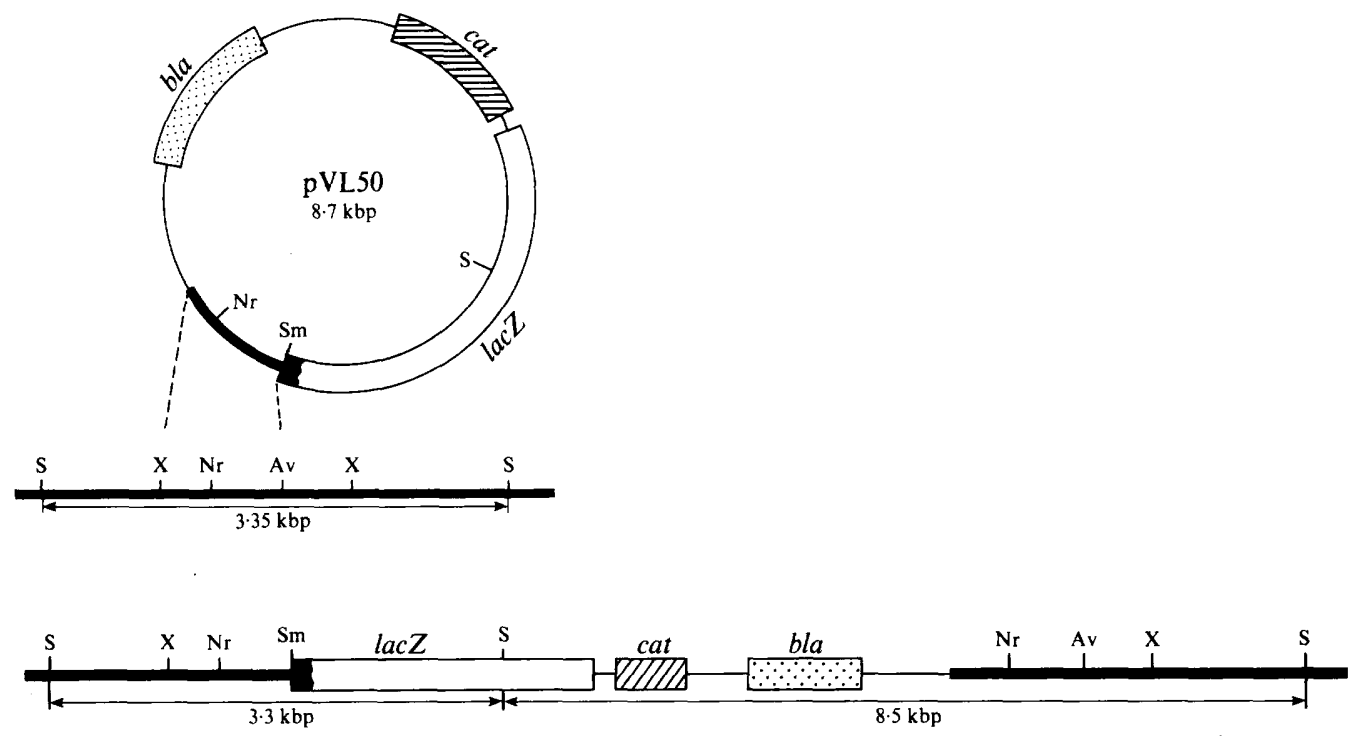

Fig. 2. Schematic representation of the insertion of a transcriptional spoVE: :lacZ fusion into the $B$. subtilis chromosome. The upper part of the figure shows the structure of plasmid pVL50, carrying a transcriptional spoVE: :lacZ fusion. Below is depicted the restriction map of the area around the spoVE locus. Integration of pVL50 introduces an additional SstI site. Predicted sizes for the new SstI fragments are given in the bottom part of the figure. Restriction sites: Av, Aval; Nr, NruI; S, SstI; Sm, SmaI; X, XhoI.

In order to confirm that a Campbell-type integration had taken place, chromosomal DNA from several $\mathrm{Cm}^{\mathrm{R}}$ clones was analysed by Southern blotting. The DNA of $\mathrm{Cm}^{\mathrm{R}}$ clones resulting from crosses of strain 168 with pVL50 was digested to completion with SstI, separated on $0.7 \%$ agarose and blotted onto a nitrocellulose membrane. Blots were hybridized to the $4.9 \mathrm{kbp}$ BamHI fragment of pSGMU23 (Errington, 1986) labelled with ${ }^{32} \mathrm{P}$. This probe hybridized strongly to two fragments, 3.3 and $8.5 \mathrm{kbp}$ in size. These observations agree well, within experimental error, with insertion of plasmid pVL50 by a Campbell mechanism as outlined in Fig. 2.

During these experiments about $20 \%$ of the $\mathrm{Cm}^{\mathrm{R}}$ clones generated by transformation of strain 168 with plasmid pVL50 were found to have an altered pattern of hybridization, with only an $8.5 \mathrm{kbp}$ fragment appearing in Sst $\mathrm{l}$-digested DNA. Similar observations were made during experiments to define the size of transcriptional unit of the spoVE locus (Piggot et al., 1986). The reasons for the appearance of such clones are not clear and they were excluded from subsequent experiments.

\section{Expression of the spoVE : :lacZ fusion under developmental control}

Having established that strain BS50 (transcriptional fusion) contained the appropriate plasmid insertion, I set out to study the expression of the spoVE gene in sporulating $B$. subtilis cells. The results of these experiments are presented in Fig. 3. Strain BS50 was grown in CH medium and induced to sporulate by transfer to resuspension medium. Samples were collected at appropriate time intervals and $\beta$-galactosidase activity was assayed.

The activity of $\beta$-galactosidase in strain BS50 appeared to be considerably higher than the non-specific $\beta$-galactosidase background activity found in the parental strains MB75 and 168 . Significant synthesis of $\beta$-galactosidase began about $40 \mathrm{~min}$ after the induction of sporulation. The activity continued to increase for another $5 \mathrm{~h}$, reaching a peak between $t_{5}$ and $t_{6}$ and exceeding the background level by almost 10 times (Fig. 3).

The activity of $\beta$-galactosidase in a strain carrying an integrated copy of plasmid pLM14 was determined in analogous experiments and was found to be similar to that of strain BS50 (data not shown). 


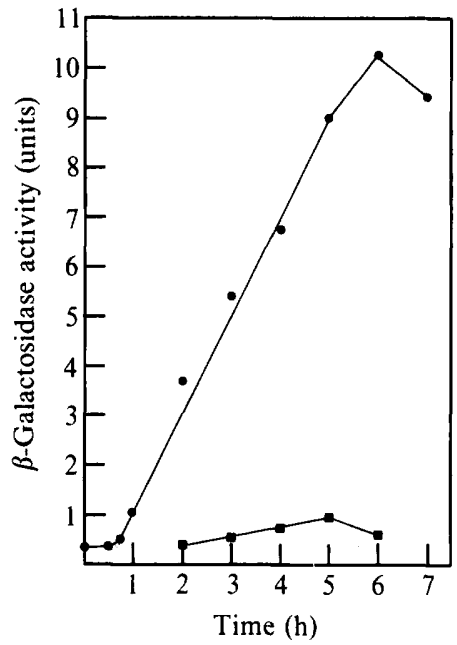

Fig. 3

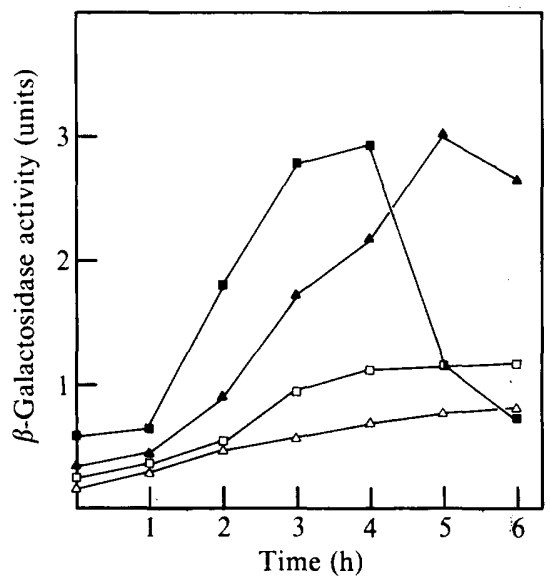

Fig. 4

Fig. 3. spoVE-regulated expression of the $\operatorname{lac} Z$ gene in $B$. subtilis. $\beta$-Galactosidase activity was monitored in strain BS50, which carries a transcriptional spoVE::lacZ fusion (pVL50; 0 ). The parental strain 168 (contains no fusion; $\square$ ) was assayed to determine non-specific background $\beta$ galactosidase activity. Strains were induced to sporulate by the method of Sterlini \& Mandelstam (1969) and $\beta$-galactosidase activity was measured at hourly intervals as described by Miller (1972).

Fig. 4. Effect of mutations in the $\operatorname{spoOA}(\mathbf{\Lambda}), \operatorname{spoOB}(\square), \operatorname{apoOH}(\square)$ and $\operatorname{spoOK}(\triangle)$ loci on the expression of spoVE: :lacZ. spo0 mutants bearing the transcriptional spoVE: :lacZ fusion were grown and induced to sporulate as described by Sterlini \& Mandelstam (1969).

\section{Table 2. Effect of mutations on various spo loci on expression of the spoVE gene}

The transcriptional spoVE: $: \operatorname{lac} Z$ fusion was transferred into the appropriate genetic background by transformation and cells containing a chromosomal insertion were tested for $\beta$-galactosidase activity as described in Methods. Assays were performed at least twice with two independently isolated strains. +, Activity reaching $30 \%$ or more of that detected in the $\mathrm{Spo}^{+}$background; - , always less than $10 \%$.

$\begin{array}{cccc}\begin{array}{c}\text { Mutated } \\ \text { locus }\end{array} & \begin{array}{c}\beta \text {-Galactosidase } \\ \text { activity }\end{array} & \begin{array}{c}\text { Mutated } \\ \text { locus }\end{array} & \begin{array}{c}\beta \text {-Galactosidase } \\ \text { activity }\end{array} \\ \text { spo0A } & + & s p o 0 H & - \\ \text { spoOB } & + & s p o 0 J & +^{*} \\ \text { spoOD } & + & s p o 0 K & - \\ \text { spoOE } & + & \text { spoIIA } & + \\ \text { spoOF } & + & \text { spoIIG } & + \\ \text { spoOG } & + & \text { spoVG } & +\end{array}$

${ }^{*} \beta$-Galactosidase activity was $32 \%$ and $95 \%$ in strains 93.2 (spo0J93) and 87.2 (spo0J87) respectively.

\section{Effect of mutations in various spo loci on transcription of the spoVE gene}

The finding that expression of the spoVE gene can be detected as early as $40 \mathrm{~min}$ after the induction of sporulation prompted an examination of its possible dependence on the spoO loci, which are known to be responsible for the initiation of development.

DNA extracted from strain BS50, harbouring the transcriptional spoVE : :lacZ fusion, was introduced into several spo0 mutants by transformation, and $\mathrm{Cm}^{\mathrm{R}}$ clones were screened for the Lac phenotype on Schaeffer's agar supplemented with MUG. (During these experiments about $90 \%$ of the $\mathrm{Cm}^{\mathrm{R}}$ clones were found to carry the lac $Z$ gene.) To assay quantitatively the level of expression of the hybrid spoVE: :lac gene in various mutants, $\beta$-galactosidase activity was determined using $o$-nitrophenyl $\beta$-D-galactoside as a substrate. The results showed that mutations in $5 p 00 \mathrm{~K}$ or $\mathrm{spoOH}$ loci abolished the synthesis of $\beta$-galactosidase, but mutations in 
spo0A, spoOB, spo0D, spo0E, spoOF or spo0G reduced the level of $\beta$-galactosidase activity by about $70 \%$ (Table 2, Fig. 4). Two mutations in the spo0J locus differed consistently in their effect on the expression of the spoVE::lacZ fusion. Mutation spo0J93 reduced the level of $\beta$ galactosidase activity by about $70 \%$, but mutation $s p o 0 J 87$ had little effect on the synthesis of $\beta$-galactosidase. Mutations in spoIIA, spoIIG or spoVG were without significant effect.

\section{DISCUSSION}

The view that the morphological changes which occur late in spore formation in $B$. subtilis could be the result of interactions between components synthesized much earlier is receiving experimental support as the number of cloned and characterized 'late' loci increases. Several stage V loci (spoVG, spoVK, spoVM and spoVN) begin to be transcribed within $2 \mathrm{~h}$ of the onset of sporulation (Losick et al., 1986), and transcription of the spoVA operon begins at about $t_{2.5}$ (Savva \& Mandelstam, 1985, 1986; Errington \& Mandelstam, 1986). My results have now shown that the spoVE locus is also transcribed several hours before its product is believed to be required.

By constructing the transcriptional spoVE : : lacZ fusions (plasmids pVL50 and pLM14) I was able to determine more precisely the time at which expression of this locus begins. In these gene fusions, synthesis of the hybrid protein with $\beta$-galactosidase activity is initiated from a translational start point derived from another developmental $B$. subtilis gene, spoIIAA (Errington, 1986). As can be seen from the data presented in Fig. 3, transcription of the spoVE gene started about $40 \mathrm{~min}$ after sporulation was initiated and continued until at least $t_{5}$. These results, coupled with the observation that $\beta$-galactosidase activity during the exponential phase of growth does not exceed the background level, indicate that the time of spoVE induction is determined by the regulatory system of sporulation. They also suggest that transcription of the spoVE gene occurs well before asymmetric septation (stage II) is completed; unless expression of the gene involves post-transcriptional control it follows that the protein product may be present not only in the mother cell (de Lencastre \& Piggot, 1979) but also in the forespore. If that is the case, one could explain why previous attempts to obtain complementation of the spoVE locus by protoplast fusion were unsuccessful (Dancer \& Mandelstam, 1981). It could be argued that at the time when protoplast fusion was carried out $\left(t_{3}\right)$, a faulty spoVE product had already interacted irreversibly with some other component(s) and addition of the undamaged spoVE product occurred too late to restore the sporulation sequence.

By introducing the transcriptional spoVE : : lac Z fusion into nine stage 0 mutants I was able to examine the effect of the spoO genes on the induction of spoVE. Mutations in the $s p o O H$ and spoOK loci almost entirely blocked production of $\beta$-galactosidase activity; the remaining stage 0 mutations had less effect: the level of $\beta$-galactosidase was reduced to about $30 \%$ by mutations in spo0A, spo0B, spo0D, spo0E, spoOF or spoOG (Fig. 4, Table 2). While mutation spo0J93 reduced the level of $\beta$-galactosidase activity to about $30 \%$, mutation spo0J87 had very little effect (Table 2). This is in keeping with the results of Clarke \& Mandelstam (1987), who also found that this latter mutation blocked development but allowed expression of other sporulation operons.

It has previously been pointed out that the area lying upstream from the translation initiation site of the spoVE gene shows homology with the spoVG promoters (Banner et al., 1983; Bugaichuk \& Piggot, 1986). Analysis of the spo0-dependent regulation of the spoVE transcription activity points to further similarities between these two genes. All the spo0 loci except spoOA and $s p o O B$ affect transcription of spoVE and spoVG in a similar fashion. In the absence of a clear understanding of the functions of the $\operatorname{spo} 0 A$ and $\operatorname{spo} O B$ loci it is difficult to assess the significance of the dependence of spoVE transcription on these genes. Dependence of the two genes on the $\mathrm{spoOH}$ locus may be significant. The recently discovered homology with known sigma factors suggests that the product of the $\mathrm{spoOH}$ gene is a new form of sigma specis (I. Smith, personal communication). This conclusion agrees quite well with the proposed role of $s p o 0 H$ in transcriptional regulation of the spoVG gene (Zuber \& Losick, 1985). It seems plausible that the $s p o 0 H$ product may interact with the spoVE promoter(s) in a similar way. 
To investigate the possible role of the $\sigma^{29}$ factor (Trempy et al., 1985) and what is currently known as the sigma-IIAC factor (Errington et al., 1985; Yudkin, 1987) in expression of spoVE, the hybrid spoVE::lacZ gene was transferred to strains 55.3 (spoIIG), 69 (spoIIAA69) and MY2000.63 (spoIIAC63). The pattern of $\beta$-galactosidase expression in these strains was not found to be significantly different from that in the wild-type. This observation agrees with available data on transcriptional activation of the spoIIG and spoIIA loci (reviewed by Doi \& Wang, 1986) and indicates that the initiation of transcription of the spoVE gene does not require participation of these sigma factors.

Four of the stage $\mathrm{V}$ loci, spoVA, spoVC, spoVD and spoVF, are in a line of expression dependent on spoIIA, spoIIG, etc. (Holland et al., 1987). By contrast, spoVE and spoVG do not seem to be part of this dependent sequence of gene expression. Clearly, more information about the function of these loci is needed before we can interpret dependence relationships in terms of molecular interactions, which are the essence of the sporulation process.

I am grateful to Professor J. Mandelstam for his support and invaluable encouragement throughout this research project and to Dr M. D. Yudkin for critical reading of the manuscript and advice. I thank Dr J. Errington for donation of plasmids and $\mathrm{Mr} \mathrm{D}$. Ramsay for the art work. This work was supported by the Science and Engineering Research Council.

\section{REFERENCES}

ANAgnostopoulos, C. \& SPIzizen, J. (1961). Requirements for transformation in Bacillus subtilis. Journal of Bacteriology 81, 741-746.

Banner, C. D. B., Moran, C. P., JR \& Losick, R. (1983). Deletion analysis of a complex promoter for a developmentally regulated gene from Bacillus subtilis. Journal of Molecular Biology 168, 351-365.

Birnboim, H. C. \& Doly, J. (1979). A rapid alkaline extraction procedure for screening recombinant plasmid DNA. Nucleic Acids Research 7, 1513-1523.

BugaichuK, U. D. \& Piggot, P. J. (1986). Nucleotide sequence of the Bacillus subtilis developmental gene spoVE. Journal of General Microbiology 132, 18831890.

Clarke, S. \& Mandelstam, J. (1987). Regulation of stage II of sporulation in Bacillus subtilis. Journal of General Microbiology 133, 2371-2380.

Dancer, B. N. \& Mandelstam, J. (1981). Complementation of sporulation mutations in fused protoplasts of Bacillus subtilis. Journal of General Microbiology 123, 17-26.

Dion, P. \& MANDelsTaM, J. (1980). Germination properties as marker events characterizing later stages of Bacillus subtilis spore formation. Journal of Bacteriology 141, 786-792.

DoI, R. H. \& WANG, L.-F. (1986). Multiple procaryotic ribonucleic acid polymerase sigma factors. Microbiological Reviews 50, 227-243.

ERRINGTON, J. (1986). A general method for fusion of the Escherichia coli lac Z gene to chromosomal genes in Bacillus subtilis. Journal of General Microbiology 132, 2953-2966.

ERRINGTON, J. \& MANDELSTAM, J. (1986). Use of a lacZ gene fusion to determine the dependence pattern and the spore compartment expression of sporulation operon spoVA in spo mutants of Bacillus subtilis. Journal of General Microbiology 132, 2977-2985.

ERrington, J., ForT, P. \& MANDElstam, J. (1985). Duplicated sporulation genes in bacteria: implications for simple developmental system. FEBS Letters 188, 184-188.
HanahaN, D. (1983). Studies on transformation of Escherichia coli with plasmids. Journal of Molecular Biology 166, 557-580.

Holland, S., Cutting, S. \& Mandelstam, J. (1987). The possible DNA-binding nature of the regulatory proteins encoded by spoIID and ger $E$, involved in the sporulation of Bacillus subtilis. Journal of General Microbiology 133, 2381-2391.

Jenkinson, H. F., KaY, D. \& Mandelstam, J. (1980). Temporal dissociation of late events in Bacillus subtilis sporulation from expression of genes that determine them. Journal of Bacteriology 141, 793805.

Jenkinson, H. F., SAwyer, W. D. \& Mandelstam, J. (1981). Synthesis and order of assembly of spore coat proteins in Bacillus subtilis. Journal of General Microbiology 123, 1-16.

Lencastre, H. De \& Piggot, P. J. (1979). Identification of different sites of expression for spo loci by transformation of Bacillus subtilis. Journal of General Microbiology 114, 377-389.

Losick, R., Youngman, P. \& Piggot, P. J. (1986). Genetics of endospore formation in Bacillus subtilis. Annual Review of Genetics 20, 625-669.

Maniatis, T., Fritsch, E. F. \& SambrooK, J. (1982). Molecular Cloning: a Laboratory Manual. Cold Spring Harbor, NY: Cold Spring Harbor Laboratory.

Messing, J., Crea, R. \& Seeburg, P. H. (1981). A system for shotgun DNA sequencing. Nucleic Acids Research 9, 309-321.

Miller, J. H. (1972). Experiments in Molecular Genetics. Cold Spring Harbor, NY: Cold Spring Harbor Laboratory.

Norrander, J., Kempe, T. \& Messing, J. (1983). Construction of improved M13 vectors using oligonucleotide-directed mutagenesis. Gene 26, 101-106.

Piggot, P. J., Curtis, C. A. M. \& Lencastre, H. DE (1984). Use of integrational plasmid vectors to demonstrate the polycistronic nature of a transcriptional unit (spoIIA) required for sporulation of 
Bacillus subtilis, Journal of General Microbiology 130 , 2123-2136.

Piggot, P. J., Chak, K.-F. \& Bugaichuk, U. D. (1986). Isolation and characterization of a clone of the spoVE locus of Bacillus subtilis. Journal of General Microbiology 132, 1875-1881.

SavVA, D. \& Mandelstam, J. (1985). Use of cloned spoIIA and spoVA probes to study synthesis of mRNA in wild-type and asporogenous mutants of Bacillus subtilis. In Molecular Biology of Microbial Differentiation, pp. 55-59. Edited by P. Setlow \& J. Hoch. Washington, DC: American Society for Microbiology.

Savva, D. \& Mandelstam, J. (1986). Synthesis of spoIIA and spoVA mRNA in Bacillus subtilis. Journal of General Microbiology 132, 3005-3011.

Schaeffer, P., IONESCo, H., Ryter, A. \& Balassa, G. (1965). La sporulation de Bacillus subtilis: étude génétique et physiologique. Colloques Internationaux du Centre National de la Recherche Scientifique 124, 553-563.

Sterlini, J. \& MandelstaM, J. (1969). Commitment to sporulation in Bacillus subtilis and its relationship to development of actinomycin resistance. Biochemical Journal 113, 29-37.

Trempy, J. E., Bonamy, C., Szulmajster, J. \& Haldenwang, W. G. (1985). Bacillus subtilis sigma factor sigma-29 is the product of the sporulationessential gene spollG. Proceedings of the National
Academy of Sciences of the United States of America 82, 4189-4192.

YANiSCh-PERRon, C., Vieira, J. \& Messing, J. (1985). Improved M13 phage cloning vectors and host strains: nucleotide sequences of the M13mp18 and pUC19 vectors. Gene 33, 103-119.

Youngman, P., Perkins, J. P. \& Sandman, K. (1985a). Use of the Tn917-mediated transcriptional gene fusion to $l a c Z$ and $c a t-86$ for the identification and study of spo genes in Bacillus subtilis. In Molecular Biology of Microbial Differentiation, pp. 47-54. Edited by P. Setlow \& J. A. Hoch. Washington, DC: American Society for Microbiology.

Youngman, P., Zuber, P., Perkins, J. B., Sandman, K., IGo, M. \& Losick, R. (1985b). New ways to study developmental genes in spore-forming bacteria. Science 228, 285-291.

YUDKIN, M. D. (1987). Structure and function in a Bacillus subtilis sporulation-specific sigma factor: molecular nature of mutations in spoIIAC. Journal of General Microbiology 133, 475-481.

ZUBER, P. \& Losick, R. (1983). Use of lacZ fusion to study the role of the spo0 genes of Bacillus subtilis in developmental regulation. Cell 35, 275-283.

ZUBER, P. \& Losick, R. (1985). spoOH: a developmental regulatory gene for promoter utilization in Bacillus subtilis. Cold Spring Harbor Symposia on Quantitative Biology 50, 483-488. 